\title{
O Modo de Produção: Categoria do Materialismo Histórico
}

Magda Maria Colao *

Um capitalismo humano, social, verdadeiramente democrático e equiitativo é mais irreal e utópico que o socialismo. O capitalismo é estruturalmente antitético à democracia não somente por razão óbvia de que nunca houve uma sociedade capitalista em que a riqueza não tivesse acesso privilegiado ao poder, mas também, e principalmente, porque a condição insuperável de existência do capitalismo é o fato de a mais básica das condições de vida. as exigências mais básicas da reprodução social, ter de se submeter aos ditames da acumulação de capital e as "leis"do mercado. Isso quer dizer que o capitalismo coloca necessariamente mais e mais esferas da vida fora do alcance da responsabilidade democrática”. ( WOOD, 2003, p. 8)

Resumo: O modo de produção é a categoria básica, fonte, do materialismo histórico. Em seu seio podemos encontrar todas as categorias próprias do materialismo histórico. Porém, as categorias dessa ciência social são as forças produtivas (ser humano, ferramentas, máquinas, tecnologia) e as relações de produção (entre assalariados e empresários, entre assalariados, e entre empresários). As relações de produção, junto às outras categorias do materialismo histórico, fundamentalmente, produzem as mudanças e transformações sociais.

Palavras-Chave: Trabalho. Capitalismo. Economia: história. Classe social.

Na obra Contribuição para a crítica da economia política, Marx comenta sobre o modo de produção nos seguintes termos:

Doutora em Educação, psicóloga e professora da Universidade de Caxias do Sul (UCS)

Movimento, Porto Alegre, v.12, n. 02, p. 143-169, maio/agosto de 2006. 
O primeiro trabalho que empreendi para esclarecer as dúvidas que me assaltavam foi uma revisão "Crítica da Filosofia do direito de Hegel”, trabalho cuja introdução apareceu nos Anais franco-alemães, publicado em Paris em 1844. Nas minhas pesquisas cheguei à conclusão de que as relações jurídicas, assim como as formas de Estado, não podem ser compreendidas por si mesmas, nem pela dita evolução geral do espírito humano, inserindo-se pelo contrário nas condições materiais de existência de que Hegel, à semelhança dos ingleses e franceses do século XVIII, compreende o conjunto pela designação de "sociedade civil"; por seu lado, a anatomia da sociedade civil deve ser procurada na economia política. Tinha começado o estudo desta em Paris, continuando-o em Bruxelas. A conclusão geral a que cheguei e que uma vez adquirida, serviu de fio condutor dos meus estudos, pode formular-se, resumidamente assim: "na produção social de sua existência, os homens estabelecem relações determinada, necessárias, independentes da sua vontade, relações de produção que correspondem a um determinado grau de desenvolvimento das forças produtivas materiais. $O$ conjunto destas relações de produção constitui a estrutura econômica da sociedade, a base concreta sobre a qual se eleva uma superestrutura jurídica e política e a qual correspondem determinadas formas de consciência social. $O$ modo de produção da vida material condiciona o desenvolvimento da vida social, política e intelectual em geral. Não é a consciência dos homens que determina o seu ser; é o seu ser social que, inversamente, determina a sua consciência. (MARX, 1983, p. 24)

Movimento, Porto Alegre, v.12, n. 02, p. 143-169, maio/agosto de 2006. 


\section{Breve nota priliminar}

Creio que a categoria do modo de produção e pesquisa ${ }^{1}$ não somente é a principal categoria, a categoria fundamental do materialismo histórico, mas também, como disse Engels, uma das criações mais geniais de Marx. Claramente isso o destaca Wood (2003) quando expressa que o modo de produção é o "conceito mais operacional do materialismo histórico”. E eu acrescentaria: a mais rica, a mais complexa das categorias do materialismo histórico.

O nascimento e a concepção geral da categoria do materialismo histórico revelam, não só o gênio de Marx, mas também seu

\footnotetext{
O conhecer o modo de produção, no qual está inserida sua pesquisa, é fundamental para o pesquisador. Poderíamos dizer que se o pesquisador não conhece as características que definem determinado modo de produção, seu trabalho será cego, sem espírito criativo. Quando mais será pura repetição ou uma soma de conceitos vazios, elaborada no ar. E isso, infelizmente, ocorre freqüentemente em nosso meio acadêmico. Muitas pesquisas são orientadas por teorias, geralmente criadas noutro mundo, o mundo desenvolvido, que está longe de nossa realidade.

O Modo de Produção representa uma determinada formação social, o que significa que Modo de Produção represen una determinada for assinala os caracteres fundamentais dessa formação social. O Modo de Produção da formação social primitiva apresentava como caracteristica essencial o trabalho coletivo, através do qual, todos produziam e todos se repartiam o que produziam. A propriedade dos meios de produção era do coletivo social.

Entretanto, no Modo de Produção Capitalista, no qual estamos submersos, os meios de produção pertencem a uma minoria. E o que produz o ser humano, como trabalhador, não Ihe pertence. A produção se torna mercadoria, e inclusive a força de trabalho do ser humano é mercadoria, cujo valor também varia no mercado. Como essa minoria é absolutamente dominante, é também proprietária da tecnologia. $\mathrm{E}$ isso tem significado, que a tecnologia substitua o ser humano no processo produtivo. Como conseqüência disso, o trabalho desaparece para o trabalhar manual e intelectual. E falta de trabalho para o se humano, aumenta a miséria no mundo.

No campo da educação, o modo de produção capitalista, estimula o triunfo individual, o egoísmo. Desenvolve a educação privada e trata de destruir a educacão pública. Os educadores que trabalham para a educaça pública rectún sários reduzidos que apeeducado permitem nas thes permitem sobreviver. E a formação desses educadores que servirão na educação pública também é mesquinha, porque, segundo esse modo de produção, as classe receber um nível de escolaridade que lhes permita

De maneira que o Modo de Produção, na pesquisa, torna-se a chave que abrirá as portas pelas quais ela entrará e caminhará. O pesquisador saberá o que pode encontrar ness realidade. Sua pesquisa deverá ressaltar os caracteres que apresenta o modo de produção, porém ela será absolutamente inútil, se não apresenta os caminhos que se podem seguir para transformar esse modo de produção injusto.
}

Movimento, Porto Alegre, v.12, n. 02, p. 143-169, maio/agosto de 2006. 
profundo conhecimento da história da humanidade. Conhecimento sentido, não como uma estrutura pétrea, situado no fundo de uma sala de museu, mas com uma dimensão heurística, capaz de abrir o espírito a novas verdades, a novos descobrimentos intelectuais.

Por que, que é o modo de produção, se não o berço de toda a cultura da humanidade, do ser humano como ser pensante, com necessidades materiais, com necessidades espirituais, com esperanças, com desejos de chegar mais alto na compreensão do que é o ser humano, a vida, o mundo? Porque no modo de produção reside o básico da existência da mulher e do homem: a busca de maneiras de satisfazer suas necessidades de existir, de sobreviver, e ao mesmo de criar, de transformar a realidade que lhe dá abrigo.

No modo de produção estão as forças produtivas e as relações de produção, mas também o ser social, a consciência social, a arte, a ciência, os valores, a cultura em geral. Ou seja, o ser humano como ser social, político, econômico, como cidadão, como pessoa em desenvolvimento, em criação, em processo de transformação do mundo, da vida, da sociedade.

Alguns têm falado de uma base ou de uma infra - estrutura e de uma superestrutura para desenhar a idéia do modo de produção. Talvez possa haver um fundamento para manter semelhante idéia. Porém, eu vejo o modo de produção como uma realidade dialética onde todos os processos que nele se realizam estão em perpétuo movimento, tanto os que se concretizam na especificidade do desenvolvimento das forças produtivas e das relações de produção como nos resultados que esse desenvolvimento origina. $\mathrm{O}$ que aí existe, por um lado, são expressões de contradições antagônicas e não antagônicas que estão produzindo mudanças, e dadas certas circunstâncias, também transformações. Por outro lado, sem dúvida, nessas contradições, existem pólos que são dominantes e que, em determinado momento histórico, definem o caráter, por exemplo, de cooperação ou de opressão que terão os frutos dessa relação dialética dos elementos envolvidos.

Movimento, Porto Alegre, v.12, n. 02, p. 143-169, maio/agosto de 2006. 
Essa realidade dialética do modo de produção, não permite, por exemplo, que o ser social, constituído pelas forças produtivas e as relações de produção, e a consciência social, que é resultado desse processo estabelecido ou entre as força produtivas e as relações de produção, sejam idênticos para todas as pessoas que integram determinado modo de produção. A mesma condição dialética e a idiossincrasia que caracteriza a cada pessoa tornam possível que o selo que estabelece o modo de produção nos membros que o integram apenas seja geral. Por isso, os modos de produção que são dominantemente opressores, sempre terão elementos singulares que estarão lutando contra esse predomínio injusto.

\section{0 conceito do modo de produção}

Os elementos essenciais do modo de produção, como já o expressei, são as forças produtivas e as relações de produção. Por outro lado, Marx já mostrou que o desenvolvimento da vida social está intimamente ligado ao modo de produção que lhe é próprio. Essas conclusões dos estudos de Marx originaram, muito mais tarde, uma polêmica que ainda não está, inteiramente, resolvida.

Em primeiro lugar, Marx foi acusado de evolucionista, quando descreveu que na história da sociedade tem havido uma sucessiva história de modos de produção, desde o modo de produção primitivo até chegar ao modo de produção capitalista, passando pelos modos escravista e feudal, e inclusive um modo de produção asiático que mostrava características diferenciadas aos outros modos de produção existentes na história. E anunciava Marx que o modo capitalista de produção seria substituído pelo modo socialista de produção. Mais adiante, neste breve ensaio, esclarecerei como se está tratando de rejeitar dessa acusação de evolucionista na essência do pensamento marxiano. Por ora, voltamos às forças produtivas e as relações de produção.

Movimento, Porto Alegre, v.12, n. 02, p. 143-169, maio/agosto de 2006. 
Na produção social de sua existência, os homens estabelecem relações determinadas, necessidades, independentes da sua vontade, relações de produção que correspondem a um determinado grau de desenvolvimento das forcas produtivas materiais [...]. O modo de produção da vida material condiciona o desenvolvimento da vida social, política e intelectual em gera. [...]. Em certo estádio de desenvolvimento, as forças produtivas materiais da sociedade entram em contradição com as relações de produção ou, o que é sua expressão jurídica, com as relações de propriedade no seio das quais se tinham movido até então. De formas de desenvolvimento das forças produtivas, estas relações transformam-se em seu entrave. (MARX, 1983, p. 24-25)

Esta afirmação de Marx desencadeou um debate entre os marxistas que ainda não terminou. Alguns teóricos marxistas dão primazia às formas produtivas, o que originaria um marxismo determinista tecnológico, e outros, que "situam as relações de produção e de classe num contexto trans-histórico maior de desenvolvimento tecnológico". (WOOD, 2003, p. 99-102)

Eu quero fazer alguns comentários frente a esta polêmica e inclusive, tomar partido por algum tipo de decisão. Em primeiro lugar, eu penso que no seio do modo de produção, existem as relações de produção e as forças produtivas numa dimensão dialética. Ao que parece Marx quando expressa que "em certo estado de desenvolvimento entram em contradição as forças produtivas com as relações de produção", ele está pensando em contradições antagônicas que são resolvidas somente com a destruição de uns dos pólos da contradição. Ou seja, que até esse momento, as forças produtivas e as relações de produção estavam em contradição não antagônica. Isto pretende esclarecer o que possivelmente houvesse estado ocorrendo no modo de produção. Mas não ajuda a resolver se no modo de produção são prioritárias as 
relações de produção ou as forças produtivas. Eu considero que, historicamente, as relações de produção são mais duradouras que as forças produtivas.

O mesmo homem que é a principal força produtiva no modo de produção tem uma existência relativamente breve. A tecnologia, em nosso tempo, a cada momento apresenta uma nova face. Posso dizer, dessa maneira, que as forças produtivas são efêmeras. Entretanto, as relações de produção, que tem como base, as relações de propriedade são historicamente mais sólidas. Por outro lado, as relações de produção estão relacionadas também com a troca e a distribuição da produção. Na propriedade coletiva dos meios de produção as pessoas são iguais. E a cooperação e a emulação são fundamentais no processo de produção. Quando os meios de produção são de propriedade privada existem a competição e a submissão. Por isso eu penso, e considerando também a formação acadêmica de Marx, essencialmente em história, filosofia, economia e direito, que Marx priorizava as relações de produção como responsáveis das mudanças progressivas que poderiam realizar os modos de produção.

Mas isso nos leva a referir-nos a outro problema. É a história humana a sucessão natural de modos de produção?

Wood (2003, p. 103-105) afirma que, segundo Roemer, todas as formas de exploração estão já embutidas no feudalismo. Estas formas de exploração dificultam o desenvolvimento das forças produtivas e são eliminadas pela revolução burguesa. Essa idéia, segundo Wood, representa um ponto de vista de determinismo tecnológico; ou seja, de predomínio das forças produtivas na passagem de uma sociedade de um estado inferior a outro superior. Porém Wood, ou mesmo Marx retifica sua afirmação que aparece no prefácio da Contribuição à crítica da economia política, e que citamos acima, quando expressa nos Grundrisse (WOOD, 2003, p. 105) e em $O$ Capital que "o que distingue as relações de produção pré-capitalistas é que elas oferecem aos produtores diretos

Movimento, Porto Alegre, v.12, n. 02, p. 143-169, maio/agosto de 2006. 
todos os meios de reprodução". E acrescenta Wood (2003, p.105), cintando Brenner, "que as comunidades de senhores e agricultores, através dessas relações de propriedade, tornavam possível a reprodução econômica de seus membros". Isto quer dizer que a passagem do modo de produção feudal ao modo de produção capitalista, se produziu pela "transformação das relações de propriedade existentes das regras feudais de reprodução para as novas regras capitalistas". (WOOD, 2003, p. 106)

Quero terminar este comentário preliminar, antes de desenvolver o conceito de modo de produção, que, é o que me preocupa nesta parte de meu trabalho, com uma citação de Ellen Wood que reflete claramente o que eu penso.

\begin{abstract}
A premissa aqui é que o modo de produção não existe em oposição aos "fatores sociais", e que a inovação radical de Marx em relação à economia política burguesa foi precisamente a definição do modo de produção e das próprias leis econômicas em de "fatores sociais". (WOOD, 2003, p. 31)
\end{abstract}

Para o Diccionario de Filosofia (ACADEMIA, 1984, p. 296), o modo de produção "caracteriza um tipo determinado de produção dos meios necessários para a vida do ser humano (alimentos, roupa, habitação, instrumentos de produção)". Reconhece o mencionado Diccionario, a importância essencial dessa categoria para o materialismo histórico, já que se refere aos aspectos fundamentais da vida social, política e espiritual que existe numa determinada sociedade. O modo de produção está ligado ao desenvolvimento de todos os fatores sociais e é elemento principal na configuração da sociedade toda. Nele existem as forças produtivas e as relações de produção indissoluvelmente unidas e em contradição.

Para Quintanilla (1985, p. 323-324) o modo de produção resulta da combinação específica entre um nível de desenvolvimento das forças produtivas as correspondentes relações de produção. Considera o modo de produção como um "objeto abstrato-

Movimento, Porto Alegre, v.12, n. 02, p. 143-169, maio/agosto de 2006. 
formal", o que significaria que o modo de produção se apresentaria como uma espécie de modelo para a analise das formações socioeconômicas. Ou seja, que o modo de produção não teria existência real. A formação socioeconômica, seria a instância social concreta que conteria vários modos de produção, dos quais um deles seria dominante.

Esta idéia de Quintanilla parece não concordar com as análises que ao longo de $O$ Capital realiza Marx, como posteriormente destacaremos, ao falar do modo capitalista de produção. Na realidade, Quintanilla, para defender suas idéias sobre o modo de produção e a formação socioeconômica está apoiando-se especialmente no marxismo estruturalista de Althusser, Poulantzas e Balibar que na década de setenta do século vinte teve alguma importância na representação do pensamento marxista. Porém, nesse mesmo período assinalado, e inclusive um pouco antes, tiveram Althusser e seus seguidores, críticas tão severas que, essa tendência estruturalista marxista, foi como apagada dentro do campo do pensamento marxista.

Wood (2003) é taxativa ao criticar e rejeitar a posição althusseriana, quando expressa:

A verdade que pode existir na sugestão de que a
distinção altusseriana entre modo produção e
formação social destinava-ser a tornar os mar-
xistas ducados à sombra do modelo grosseira-
mente economístico e reducionista da base/su-
perestrutura mais sensivel á especificidade his-
tórica e à complexidade da vida social não pas-
sa de meia verdade; pois a distinção atingiu
seu fim mediante a simples inserção de uma cu-
nha entre estrutura e história,criando um
dualismo rígido entre determinação e contin-
gência a que deixou as determinações estrutu-
rais mais ou menos impotentes na esfera da
explicação histórica e, na verdade, tornou-se
sem efeito o materialismo histórico como meio
de explicação do processo histórico. Foi ape-

Movimento, Porto Alegre, v.12, n. 02, p. 143-169, maio/agosto de 2006. 
nas uma forma de evadir o desafio proposto por Marx: com, o abranger a especificidade histórica, bem como a ação humana, enquanto se reconhece dentro delas a lógica dos modos de produção. (WOOD, 2003, p. 59)

\section{Os tipos de modo de produção}

Marx fala dos modos de produção em várias obras. Numa delas, Formações econômicas pré-capitalista, como o expressa o título escreve, de maneira especial dos modos de produção que existiram antes da chegada do modo de produção capitalista. É interessante destacar algumas idéias que Marx afirma, porque nos permitem compreender o modo de produção capitalista.

Diz Marx (1986) no livro citado:

Quanto mais tradicional for o próprio modo de produção, isto é, quanto mais o processo real de apropriação permanecer o mesmo, tanto mais imutável serão as velhas formas de propriedade e portanto a comunidade como um todo (Observe-se que o modo tradicional persiste por longo tempo na agricultura e, ainda mais, na combinação oriental de agricultura e manufatura). Quando os membros da comunidade tiverem adquirido, como proprietários privados, existência separada de sua existência coletiva como comunidade urbana e donos do território urbano, já surgirão condições que permitirão ao indivíduo a perda de sua propriedade, isto é, o duplo relacionamento que o torna um cidadão, com status igual, um membro de comunidade, quanto um proprietário. Na forma oriental esta perda seria difícil a menos que ocorra como resultado de influências completamente externas, pois os membros individuais da comunidade nunca estabelecem com ela relações tão independentes que tornem possível a ruptura de suas ligações (econômicas, objetivas) com a mesma. $O$

Movimento, Porto Alegre, v.12, n. 02, p. 143-169, maio/agosto de 2006. 
indivíduo está firmemente enraizado. Este é, também, um aspecto da união de manufatura e agricultura, da cidade (neste caso a aldeia) e campo. Entre os antigos, a manufatura já se apresenta como uma corrupção (negócio adequado para libertos, clientes estrangeiros ), etc. O trabalho produtivo é liberado como trabalho doméstico de pessoas livres, destinadas só aos propósitos da agricultura, serviços religiosos, guerras e tarefas comunais, como a cons trução de casas, estradas ou templos. Este de senvolvimento, a conseqüências necessárias das relações com estrangeiros e escravos, da ânsia de trocar o produto excedente, etc., com ele o homem objetivamente individual, isto é, o indivíduo determinado como um grego, um romano, etc. A troca, o endividamento, etc., surgem o mesmo efeito. (MARX, 1986, p. 88-89).

A primeira frase da citação de Marx colocada acima: "Quanto mais tradicional seja o modo de produção, isto é, quanto mais o processo de produção permanecer o mesmo, tanto mais imutável serão as velhas formas de propriedade e portanto, também a comunidade como um todo", (MARX, 1986, p. 88), abre variadas perspectivas de análise dessa afirmação. Está, em primeiro lugar, reafirmando que um modo de produção baseado no campo da agricultura manter-se-á muito mais tempo em sua forma tradicional. Devemos entender então, que o modo de produção que tenha como fundamento o desenvolvimento industrial estará muito mais disposto às mudanças que outros modos baseados na agricultura e na manufatura. Isto também pode significar que o modo de produção capitalista pode ser considerado, dentre os tipos de modos de produção, como francamente revolucionário, especialmente se o consideramos do ponto de vista do desenvolvimento das forças produtivas. Por outro lado, ao que parece, o desenvolvimento da forças produtivas até limites não previsíveis, tende a assegurar a permanência do modo de produção capitalista, especialmente quando o modo de produção capitalista tem realizado mudanças impor-

Movimento, Porto Alegre, v.12, n. 02, p. 143-169, maio/agosto de 2006. 
tantes na propriedade dos meios de produção, os quais, cada vez mais deixam de ser propriedade individual para transformar-se em propriedade de grupos de empresários que se organizam em grandes companhias econômicas, chamadas multinacionais ou transnacionais, as quais chegam a produzir um mundo variado de mercadorias que em algumas ocasiões alcançam a cem mil espécies diferentes. Ou seja, o modo de produção capitalista introduz mudanças fundamentais que não são apenas nos aspectos tecnológicos das forças produtivas, mas também na forma de apropriação dos meios de produção. Por outro lado, este esforço do modo de produção capitalista, não evita a guerra que se realiza no mercado, onde as mercadorias têm, muitas vezes, que lutar para sobreviver, o que pode significar o êxito ou a derrota de uma determinada empresa. A tábua de salvação, nesses momentos de crise, é a união das grandes empresas que trabalham com tipos de mercadorias semelhantes, para evitar a concorrência que existindo, pode significar a morte da empresa. Isso, por outra parte, produz a concentração maior da riqueza mundial e, ao mesmo tempo, de acordo com os relatórios das Nações Unidas sobre Índices de Desenvolvimento Humano, a pobreza cresce em todas as regiões do mundo, o que pode significar a semente para originar mudanças radicais na realidade atual da humanidade.

\section{$4 \mathrm{O}$ modo de produção da comunidade primitiva}

Temos uma unidade original, entre uma forma específica de comunidade, ou unidade tribal, $e$ a propriedade natural relacionada com ela, ou, o que dá o mesmo, a relação com as condições objetivas de produção, tal como existentes na natureza, como o ser objetivo do indivíduo mediado pela comunidade. Ora, esta unidade que, em certo sentido, mostra-se como a forma particular de propriedade, tem sua realidade viva num modo de produção específico e este modo mostra-se, igualmente, como o relacionamento de indivíduos uns com os outros e como seu comportamento cotidiano, específi-

Movimento, Porto Alegre, v.12, n. 02, p. 143-169, maio/agosto de 2006. 
co, frente à natureza inorgânica, seu modo específico de trabalho (que sempre é trabalho familiar e muitas vezes comunal). A própria comunidade apresenta-se como a primeira grande força produtiva; tipos especiais de condições de produção (ex.: criação, agricultura), conduzem à evolução de um modo especial de produção, bem como forças produtivas especiais tanto objetivas como subjetivas, as últimas emergindo como qualidades do indivíduo. Neste caso, a comunidade e a propriedade que nela se baseia podem ser reduzidas a um estágio específico de desenvolvimento das forças produtivas dos indivíduos trabalhadores, a que correspondem relações específicas destes indivíduos entre si e com a natureza. Até certo ponto, reprodução. Depois disto, transformase em dissolução.(MARX, 1986, p. 89-90).

Desta descrição que faz Marx do que é o modo de produção primitivo, pode-se ressaltar várias idéias. Uma delas, por exemplo, é a que se refere a que "[...] a própria comunidade apresentase como a primeira grande força produtiva". Outra idéia que merece ser destacada é a do "[...] relacionamento de indivíduos uns com os outros num comportamento cotidiano específico, frente à natureza inorgânica".

Quintanilla acrescenta à estas idéias de Marx, alguns conceitos que quero destacar também. Expressa Quintanilla (1985, p. 325): "O resultado da produção agrícola se distribui entre toda a comunidade, sem que origine excedente". Esta idéia que soma o autor citado ao conceito de modo de produção primitivo, é importante porque, mais tarde, o modo capitalista especialmente, baseará grande parte de seu desenvolvimento e força, precisamente na produção excedente. Argumenta Quintanilla (1985, p. 325) que dessa maneira, produzindo exatamente para satisfazer as necessidades da comunidade, ninguém, nesta, se enriquece. Não há a possibilidade da existência de classes socais antagônicas. "A desintegração da comunidade primitiva é o resultado da agricultura

Movimento, Porto Alegre, v.12, n. 02, p. 143-169, maio/agosto de 2006. 
sedentária, na que surge o produto excedente, e com ele a desigualdade social".

\section{0 modo de produção antigo}

Quintanilla (1985, p. 325-326) expressa que a dissolução da comunidade primitiva originou, por um lado, na Ásia, o modo de produção asiático, e na Europa, o modo de produção antigo que são significativos em Atenas e Roma, por serem formas diferenciadas de modos de produção antigos. $\mathrm{O}$ estado ateniense nasce como resultado dos antagonismos que se desenvolvem no seio da sociedade gentilícia. Aparece a divisão do trabalho. Surge a pequena propriedade agrária. Despontam ofícios. Nascem os mercadores que se deslocam de tribo em tribo, o que cria problemas, porque os estrangeiros não eram reconhecidos como formando parte da tribo. Para solucionar o caso, especialmente dos mercadores, ditou-se uma constituição comum para todas as tribos. Essa constituição determinou três classes de pessoas: os nobres, os agricultores e os artesãos. Na constituição estabeleceu-se também que os cargos públicos, somente poderiam ser desempenhados pelos nobres.

O modo de produção antigo de Roma é considerado mais desenvolvido que o ateniense. As pessoas são possuidoras de terras públicas e proprietário de uma parcela. O indivíduo encontrase ligado à comunidade, a qual lhe garante sua existência com a condição de trabalhar também para o exército e participar em campanhas guerreiras. Os romanos como os gregos praticam uma espécie de democracia militar. Esta, de Roma, chegou a constituir uma classe que se apoderou de todo o poder público, especialmente do senado. Ao mesmo tempo estava-se constituindo em Roma uma plebe, sem nenhum direito político, salvo que, houvesse feito o serviço militar; então podia participar nas assembléias do povo. Esta plebe constituía o núcleo do exército romano. 


\section{0 modo de produção escravista}

O escravo é um instrumento de trabalho que o amo deve manter da mesma forma como se conserva um boi, um cavalo. A propriedade do solo é privada. Os proprietários são latifundiários. E o escravo é a forma produtiva principal. A corrupção do império romano e a invasão dos bárbaros que chegou pelo norte terminaram com este modo de produção, esclarece Quintanilla (1985, p. 326).

\section{O modo de produção asiático}

Quintanilla (1985, p. 325) expressa que com este modo de produção nasce a incipiente figura do estado e, ao mesmo tempo, se inicia a exploração de classe, porém, sem o poder da propriedade privada. Um grupo de comunidades fica sob o poder de uma comunidade superior que representa o poder de todas as comunidades. As condições para a exploração se apresentam quando a comunidade superior exige a cooperação de todas as comunidades para realizar grandes obras de irrigação, como ocorreu nos vales de Egito e da Mesopotâmia, no império inca, e outros. "O baixo nível de desenvolvimento das forças produtivas exigiu o nascimento de um poder despótico centralizado nessas regiões". A comunidade superior se apropria do solo, e os membros das comunidades restantes são despojados dos direitos de propriedade. É mantida comunitária a propriedade, porém agora como propriedade da comunidade superior.

Marx disse que havia uma:

$$
\begin{aligned}
& \text { [...] necessidade de um uso econômico e co- } \\
& \text { mum da água que, no Ocidente, levou a empre- } \\
& \text { sa privada a uma associação voluntária, como } \\
& \text { em Flandres e na Itália, obrigou, no Oriente, } \\
& \text { onde a civilização estava demasiado pouco de- } \\
& \text { senvolvida e a extensão territorial era demasia- } \\
& \text { da vasta para suscitar uma associação voluntá- } \\
& \text { ria, à interferência do poder centralizador do } \\
& \text { governo. (MARX, 1982, v. } 1, p .5104)
\end{aligned}
$$

Movimento, Porto Alegre, v.12, n. 02, p. 143-169, maio/agosto de 2006. 


\section{0 modo de produção feudal}

O modo de produção feudal implantou-se depois de um longo processo cuja origem se encontra nas formas germânicas de produção. Este modo de produção combina a propriedade coletiva da terra (florestas, pastagens) com a posse de uma parcela particular de um indivíduo. A comunidade representava os proprietários individuais. Um conselho de chefes, integrados por príncipes, resolvia ou tratava de resolver os problemas que surgiam entre os proprietários individuais. Quando o conselho era incapaz de superar as dificuldades que se apresentavam entre os indivíduos, então era a assembléia de proprietários individuais a que resolvia os problemas que pudessem apresentar-se. A assembléia também elegia os chefes militares. Pouco a pouco foi criando-se uma classe que estava constituída pelas pessoas de mais influência, e chegou a tomar o poder, e inclusive estabeleceram o direito da herança dos cargos públicos.

Com a queda do império romano, os germanos repartiram os territórios entre seus soldados que representavam a elite militar. Sobre as ruínas das tribos germânicas surgiu o estado feudal, constituído essencialmente pelos senhores e os servos.

\section{0 modo socialista de produção}

O modo socialista da produção segundo Quintanilla (1985, p. 491), se constitui com a negação do modo capitalista de produção e da luta de classes entre a o proletariado e a burguesia. $\mathrm{O}$ modo de produção socialista se caracteriza especialmente pela existência da propriedade social de todos os meios de produção. Cada membro da sociedade desfrutará dos bens que sejam necessários para sua existência como ser humano e cidadão. Desaparecem as classes sociais. E as grandes contradições antagônicas da sociedade capitalista deixam de existir e a realidade da nação socialista se mexe dentro das possibilidades que oferecem as resoluções das contradições não antagônicas.

Movimento, Porto Alegre, v.12, n. 02, p. 143-169, maio/agosto de 2006. 


\section{O modo de produção capitalista}

Quero iniciar o capítulo final de meu trabalho sobre o modo de produção, lembrando algumas idéias de Mészáros, que expressa em seu livro Para além do capital, porque o tema que ele apresenta nessa parte de sua grande obra, está muito unido às nossas experiências cotidianas de nossa linguagem, de nossa fala diária e de nosso viver. Mészáros escreve sobre a globalização, e expressa:

O termo "globalização" entrou na moda no últimos tempos, mas evita-se cuidadosamente falar sobre o tipo de "globalização" viável sobre o domínio do capital. Em vez disso, é muito mais fácil pressupor que, por sua própria natureza, a globalização não é de modo algum problemática e é realmente uma mudança necessariamente positiva que traz resultados elogiáveis para todos os interessados. É melhor que se deixe fora de qualquer questionamento legítimo o fato de que o pro cesso de globalização, como de fato o conhecemos, se afirme reforçando os centros mais dinâmicos de dominação (e exploração) do capital, trazendo em sua esteira uma desigualdade crescente e uma dureza extrema para a avassaladora maioria do povo, pois as respostas de um escrutínio crítico poderiam entrar em conflito com as políticas seguidas pelas forcas capitalistas dominantes e seus colabora dores espontâneos no "Terceiro Mundo". No entanto, com essa globalização em andamento que se apresenta como muito benéfica, nada se oferece aos países "subdesenvolvidos" além da perpetuação da taxa diferenciada de exploração. Isto está muito bem ilustrado pelos números reconhecidos pela revista The economist de Londres, segundo a qual, nas fábricas norte-americanas recentemente estabelecidas na região da fronteira norte do México, os traba-

Movimento, Porto Alegre, v.12, n. 02, p. 143-169, maio/agosto de 2006. 
lhadores não ganham mais de 7 por cento do que recebe a força de trabalho norte-americana para fazer o mesmo trabalho na Califórnia. (MÉSZÁROS, 2002, p. 63-64).

A conhecida "guerra fiscal" que se origina entre os Estados brasileiros para ganhar alguma indústria do grande capital internacional, é um recurso que usa o capitalismo para ocupar os mercados que podem dar-lhe abundantes vantagens econômicas e que foram conseguidas, de maneira oficial, com os apoios dos governos e da lei. Pouca diferença pode haver entre o "bem-estar" que alcança um operário de qualquer país em relação, por exemplo, à situação do trabalhador mexicano. Ou seja, quando determinadas forças políticas procedem dessa maneira, na realidade, os países, ao final, e os trabalhadores, em especial, terão poucos benefícios.

Todos sabemos que o berço do modo capitalista de produção nasceu na Idade Média, ao redor do século XI, quando as oficinas artesanais começaram a pagar salário aos aprendizes que nesses locais trabalhavam. Antes desse fato, o aprendiz de uma oficina, podemos dizer, tinha a possibilidade, depois de longo processo de prática, chegar a ser mestre e instalar sua própria oficina e ter aprendizes. Esse era o sistema de trabalho na Idade Média. Quando o aprendiz se torna assalariado, é possível que siga nessa condição durante toda sua vida. Parece-me, aí na oficina da Idade Média, que esteve o germe da exploração do proletário, de acordo com o modo de produção capitalista.

E com a fábrica nasce a burguesia e o proletário. E ambos crescem durante séculos. Ao redor de 1800, Engels expressa:

\footnotetext{
Por esse tempo, contudo, o modo de produção capitalista, e com ele a oposição entre burguesia e proletariado, estava ainda por desenvolver. A grande indústria acaba de aparecer na Inglaterra, era ainda desconhecida na França. (ENGELS, 1985, v. 3, p. 132)
}

Movimento, Porto Alegre, v.12, n. 02, p. 143-169, maio/agosto de 2006. 


\section{$[\ldots]$}

O novo modo de produção (capitalista) ainda estava apenas no início do seu ramo; ainda era o modo de produção normal, regular, o único possível naquelas circunstâncias. Mas já nessa altura provocava um mal-estar social gritante: era a concentração de uma população desenraizada nas piores zonas das grandes cidades, era a dissolução de todos vínculos tradicionais dos costumes, da subordinação patriarcal, da família, era o excesso de trabalho, em especial das mulheres e crianças em proporções assustadoras, era a desmoralização em massa da classe operária, de súbito a tirada para condições novas, atiradas do campo para a cidade, da agricultura para a indústria, de condições de vida estáveis para condições de vida inseguras que diariamente mudavam. (ENGELS, 1985, v. 3, p. 137).

Quintanilla (1985) apresenta alguns traços que são definidores do que é o modo de produção capitalista: é proprietário do capital e dos meios de produção, pela formação da classe de trabalhadores livres e pela formação da figura do não trabalhador. Os trabalhadores livres, no modo de produção capitalista, o único que possuem é sua forma de trabalho que vendem, por um salário, ao capitalista. Desta maneira, no modo de produção capitalista tem desaparecido o ser humano como pessoa. O único que ele tem é sua força de trabalho que é considerada como uma mercadoria, que é comprada pelo capitalista. Ou seja, o indivíduo tem valor, entretanto pode vender sua força de trabalho. O capitalista se apropria do resultado do trabalho do assalariado, o que constitui a mais valia. Isto permite ao capitalista ampliar seu capital. O modo de produção capitalista passou da livre concorrência no mercado livre de mercadorias (muitos produtores independentes oferecendo seus produtos no mercado), a sua fase monopolista nacional (concentração em poucas mãos, oligopólios) e em seguida, ao comércio mundial, através de empresas multinacionais e

Movimento, Porto Alegre, v.12, n. 02, p. 143-169, maio/agosto de 2006. 
transnacionais que, cada vez, são em menor número, aumentando em grande medida a riqueza mundial e colocando-a em poder cada vez de menos pessoas. Uma etapa importante que está vivendo o capitalismo é a do desenvolvimento do capital financeiro, em prejuízo do capital produtivo. O caráter fundamental do modo de produção capitalista reside no fato de ser proprietário dos meios de produção. Essa propriedade privada dos meios de produção contrasta com o processo de produção que é de natureza social.

Marx expressa, tratando de explicar a superprodução e a especulação excessiva no comércio:

$$
\begin{aligned}
& \text { Se o sistema de crédito é o propulsor principal } \\
& \text { da superprodução e da especulação excessiva } \\
& \text { do comércio, é só porque o processo de repro- } \\
& \text { dução, elástico por natureza, se distende até o } \\
& \text { limite extremo, o que sucede em virtude de } \\
& \text { grande parte do capital social ser aplicada } \\
& \text { por não proprietários dele que empreendem de } \\
& \text { maneira bem diversa do proprietário opera } \\
& \text { considerando receoso os limites de seu capi- } \\
& \text { tal. (MARX, } 1985, v .5, \text { p. 510) }
\end{aligned}
$$

No antigo modo de produção, os próprios produtores vendiam grande parte de sua produção diretamente ao consumidor. Entretanto, afirma Marx (1985, v.5, p. 357) no “[...] capitalismo toda a produção se torna produção de mercadorias e todos os produtos se encaminham para as mãos dos agentes de circulação."

Marx (1987, v.3, p. 29) define o modo de produção capitalista nos seguintes termos: "O modo de produção capitalista, observado em sua totalidade, é a unidade constituída por processo de produção e processo de circulação."

Marx disse como se determina o valor de uma mercadoria isolada de um conjunto grande de mercadorias: "[...] no modo capitalista de produção as condições relativas ao valor da mercadoria isolada estende-se ao valor da totalidade das mercadorias de uma espécie; não fosse a produção capitalista por natureza produ- 
ção em massa."(MARX, v.4, p. 205).

O modo de produção capitalista não ficou exclusivamente no campo fabril. Também se interessou pela agricultura. Marx expressa da seguinte maneira essa realidade:

Supomos assim que o modo de produção capitalista domina, além da atividade fabril, a agricultura, isto é, que esta é explorada por capitalistas que de saída só se distinguem do demais capitalistas pelo setor em que aplicam o capital e o trabalho assalariado mobilizado por esse capital [...]. A suposição do modo capitalista de produção se ter apoderado da agricultura, implica que ele domina todas as esferas da produção burguesa. O modo de produção capitalista desapropria o trabalhador das condições de produção e, do mesmo modo na agricultura subtrai a propriedade ao trabalhador agrícola e subordina-o a um capitalista que explora a agricultura para conseguir lucro. (MARX, 1985, v.6, p. 705-706)

Segue Marx com a explicação:

O lucro, essa forma de mais valia, mesmo quando o lucro se converta em capital, não constitui a fonte de novo capital. A mais valia passa simplesmente, de uma forma, para outra.mas não é essa mudança de forma o que faz dela capital. $O$ que funciona então como capital é a mercadoria e o valor dela. (MARX, 1985, v. 6, p. 975)

O modo de produção capitalista supõe a produção em grande escala e, ao mesmo tempo, se crê num grande consumo. Seu fim é produzir mercadorias para o mercado:

O modo de produção capitalista supõe produção em grande escala e necessariamente venda em grande escala, venda portanto ao comerciante e não ao consumidor isolado. Quando o consumidor é consumidor produtivo, ca-

Movimento, Porto Alegre, v.12, n. 02, p. 143-169, maio/agosto de 2006. 
pitalista industrial, fornecendo o capital industrial de ramo de produção meios de producão a outro ramo, há venda direta (sob a forma de encomenda, etc.) de um capitalista industrial a muitos outros. Como vendedor direto, o capitalista é seu próprio comerciante, o que ele é também quando vende a comerciante. [...] $O$ comércio de mercadorias como função do capital mercantil é condição do desenvolvimento da produção capitalista e com ela se desenvolve cada vez mais. (MARX, 1987, v.3, p. 113)

Nos povos da antiguidade, a produção de mercadorias era considerado secundário. Ainda seus membros estavam amarrados às tradições do modo de produção primitivo. Marx esclarece esta idéia nos seguintes termos:

De acordo com a produção social de produção que tem validade geral numa sociedade de produtores de mercadorias, estes tratam seus produtos como mercadorias, isto é, valores, e comparam sob a aparência material das mercadorias, seus trabalhos particulares convertidos em trabalho humano homogêneo. (MARX, 1982, v.1, p. 88)

Em O Capital, Marx (1982, v.2) descreve o processo de produção. Esse processo não surge espontaneamente. Devem apresentar-se certas condições para o que dinheiro, os meios de produção e a mercadorias sejam capital.

Como os meios de produção e os de subsistência dinheiro e mercadoria em si mesmos não são capital. Tem de haver antes uma transformação que só pode ocorrer em determinadas circunstâncias. Vejamos, logo, a seguir, a que se reduzem, em suma essas circunstâncias. Duas espécies bem diferentes de possuidores de mercadorias têm de confrontar-se e entrar em contato de um lado, o proprietário de dinheiro, de meios de produção e meios de subsistência, empenhados em aumentar a soma de valores que

Movimento, Porto Alegre, v.12, n. 02, p. 143-169, maio/agosto de 2006. 
possui, comprando a força de trabalho alheia e, de outro, os trabalhadores livres, vendedores da própria força de trabalho $e$, portanto, de trabalho. Trabalhadores livres em dois sentidos, porque não são parte direta dos meios de produção, como escravos e servos, e porque não são donos dos meios de produção, como o camponês autônomo, estando assim livres e desembaraçados deles. Estabelecidos estes dois pólos do mercado, ficam dadas as duas condições básicas do modo de produção capitalista. O sistema capitalista pressupõe a dissociação entre os trabalhadores e a propriedade dos meios pelos quais realizam o trabalho. Quando a produção capitalista se torna independente, não se limita a manter essa dissociação, mas a reproduz em escada cada vez maior. O processo que cria o sistema capitalista consiste apenas no processo que retira ao trabalhador a propriedade de seus meios de trabalho, um processo que transforma em capital os meios sociais de subsistência e os de produção e converte em assalariado os produtores diretos. A chamada acumulação primitiva é apenas o processo histórico que dissocia o trabalhador dos meios de produção. É considerada primitiva porque cons titui a pré-história do capital de produção capitalista. A estrutura econômica da sociedade capitalista nasceu da estrutura econômica da sociedade feudal. A decomposição desta liberou elementos para a formação daquela. O produtor direto, o trabalhador, só pode dispor de sua pessoa depois que deixou de estar vinculado à gleba e de ser escravo ou servo de outra pessoa. Para vender livremente sua força de trabalho, levando sua mercadoria a qualquer mercado, tinha ainda de livrar-se do domínio das corporações, dos re gulamentos a que elas subordinam os aprendizes e oficiais e das prescrições com que entravavam o trabalho. (MARX, 1982, v. 2, p. 829).

Movimento, Porto Alegre, v.12, n. 02, p. 143-169, maio/agosto de 2006. 
Como é importante o que expressam Marx e Engels em $A$ ideologia alemã, quando se referem especificamente ao modo de produção e a sua influência sobre o desenvolvimento do indivíduo, ser humano. Nessa obra, escrita entre 1845 e 1846, quando apenas havia terminado Crítica à filosofia do direito de Hegel que, como já expressei, foi no estudo dessa obra que nasceu a idéia da categoria do modo de produção. De maneira, que $A$ ideologia Alemã, recolhe as primeiras reflexões que sobre o modo de produção Marx e Engels estavam elaborando, e que, em seguida Marx aprofundaria em Contribuição á crítica da economia políti$c a$ e, de maneira singular, em $O$ capital, entretanto o fazia também Engels em Do socialismo utópico ao socialismo científico publicado em 1875. Dizem Marx e Engels:

O modo como os homens produzem seus meios de vida depende, em primeiro lugar, da natureza dos próprios meios de vida encontrados e a reproduzir. Este modo de produção não deve ser considerado no seu mero aspecto de reprodução da existência física dos indivíduos. Trata-se já, isso sim, de uma forma determinada da atividade destes indivíduos, de uma forma determinada de exprimirem sua vida, de um determinado modo de vida dos mesmos. Como exprimem sua vida, assim os indivíduos são. Aquilo que eles são, coincide, portanto, com sua produção, com o que produzem e também como produzem. Aquilo que os indivíduos são, depende, portanto, das condições materiais da sua produção. (MARX; ENGELS, 1984, p. 15)

Mais adiante, em A ideologia Alemã, Marx e Engels expressam:

A produção da vida, tanto da própria, no trabalho, como da alheia, na procriação, surge agora imediatamente e como uma dupla relacão: por um lado, como relação natural, por outro lado, como relação social, social no sentido em que aqui se entende a cooperação de vários indivíduos seja em que circunstâncias 


\begin{abstract}
for e não importa de que modo e com que fim. Daqui resulta que determinado modo de produção, ou fase, industrial, esta sempre ligado a um determinado modo de cooperação, ou fase social, e este modo da cooperação é ele próprio uma força produtiva, e que quantidade das forças produtivas acessiveis aos homens condiciona o estado da sociedade, e portanto a "história da humanidade" tem de ser sempre estudada e tratada em conexão com a história da indústria e da troca (MARX E ENGELS, 1984, p. 32-33).
\end{abstract}

Não podemos fugir do desejo nesta breve lembrança de $A$ ideologia alemã de considerar uma afirmação célebre de Marx e Engels (1984, p. 56): "As idéias da classe dominante são, em todas as épocas, as idéias dominantes, ou seja, a classe que é o poder material dominante da sociedade, é, ao mesmo tempo, o seu poder espiritual dominante".

The production way: category of the historical materialism.

Abstract: The production way is the basic category, source of the historical materialism. In its midst we can find all the categories pertaining to the Historical Materialism. However, the categories of this social science are the productive forces (human being, tools, machines, technology) and the production relations (between employees and employers, among employees and among employers). The production relations together with the other categories of the historical materialism, fundamentally, create the changes and social transformations.

Keywords: Work. Capitalism. Economics: history. Social Class. 


\begin{abstract}
El modo de producción: categoría del materialismo historico.

Resumen: El modo de producción capitalista es la categoría básica, fuente del materialismo histórico. En su interior se puede encontrar todas las categorías propias del materialismo histórico. Sin embargo, las categorías de esta ciencia social son fuerzas productivas (ser humano, herramientas, máquinas, tecnología) y las relaciones de producción (entre asalariados y empresarios). Las relaciones de producción, en conjunto a las otras categorías del materialismo histórico, de modo fundamental, producen los cambios y las damental, producen los cambios y las transformaciones sociales.

Palabras clave: Trabajo. Capitalismo. Economia: Historia. Clase Social.
\end{abstract}

\title{
REFERÊNCIAS
}

ACADEMIA DE CIÊNCIAS DA URSS. Diccionario de filosofia. Moscou: Progresso, 1984.

ENGELS, Friedrich MARX, Karl. Obras escolhidas. Lisboa: Avante,1985. v. 3.

ENGELS, Friedrich. Do socialismo utópico ao socialismo científico. In MARX, Karl; ENGELS, Friedrich. Obras escolhidas. Lisboa: Avante, 1985. v. 3.

MARX, Karl. Formações econômicas pré-capitalistas. 5. ed. Rio de Janeiro: Paz e Terra, 1986.

MARX, Karl Contribuição à crítica da economia política. 2ed. São Paulo: Martins Fontes, 1983.

MARX, Karl. O capital. 8.ed. São Paulo:DIFEL, 1982. v.1: O processo de produção do capital.

MARX, Karl. A dominação britânica na Índia. In MARX, Karl; ENGELS, Friedrich. Obras escolhidas. Lisboa: Avante, 1985. v.3.

MARX, Karl. O capital. 4. ed. São Paulo: DIFEL. 1985. v.6: O processo global de produção capitalista.

MARX, Karl. O capital. 5.ed. São Paulo: DIFEL, 1987. v. 3: O processo de circulação do capital.

Movimento, Porto Alegre, v.12, n. 02, p. 143-169, maio/agosto de 2006. 
MARX, Karl. O capital. 8.ed. São Paulo: DIFEL, 1982. v. 1: O processo de produção capitalista.

MARX, Karl. O capital. São Paulo: DIFEL, 1985. v.5: O processo global de produção capitalista.

MARX, Karl. O capital. São Paulo: DIFEL, 1987. v.4: O processo global de produção capitalista.

MARX, Karl; ENGELS, Friedrich. A Ideologia alemã: teses sobre Feuerbach. São Paulo: Moraes, 1984.

MÉSZÁROS, István. Para além do capital. São Paulo: Boitempo, 2002.

QUINTANILLA, Miguel A. Diccionário de filosofia contemporânea. 3.ed Salamanca: Sígueme, 1985.

WOOD, Ellen. Democracia contra capitalismo. São Paulo: Boitempo, 2003. 